\title{
Fibrous dysplasia and aneurysmal bone cyst of the skull base presenting with blindness: a report of a rare locally aggressive example
}

\author{
Abdullah Sulieman Terkawi ${ }^{*}$, Khalid H Al-Qahtani ${ }^{1}$,Eman Baksh², Lahbib Soualmi ${ }^{3}$, Asim El-Bagir Mohamed ${ }^{4}$, \\ Abdulrahman J Sabbagh ${ }^{3}$
}

\begin{abstract}
Fibrous dysplasia (FD) and aneurysmal bone cyst (ABC) are uncommon benign intraosseous lesions. Simultaneous occurrence of both lesions is extremely rare. We present an example of concomitant FD and ABC in a 7 year-old with left eye blindness and discharge of one month duration. Physical examination revealed a proptotic left eye and bulging of the hard palate. $C T$ and MRI are consistent with FD and ABC that involved the sphenoid and ethmoidal bones bilaterally. Incomplete combined endonasalcranial resection was performed. The patient presented five months postoperatively with a large recurrence and subsequent follow up was lost. Concomitant FD with $A B C$ may occur in paranasal sinuses and may develop rapidly and exhibit locally aggressive behavior.
\end{abstract}

\section{Introduction}

Fibrous dysplasia (FD) consists of rare and benign osseous lesions of unknown etiology. They represent $2.5 \%$ of all bone tumors and $7 \%$ of benign bone tumors [1], in young, predominantly male patients $[2,3]$. The salient pathological feature of FD consists of the replacement of medullary bone by histologically benign fibro-osseous tissue [2]. FD may present as monostotic (70\%), polystotic (30\%), or as the main feature of McCune-Albright syndrome [4]. Craniofacial bones can be affected by monostotic (25\%-30\%) and polystatic (in 50\%) lesions [5]. The most affected craniofacial bones are maxilla, mandible, frontal, sphenoid and temporal bones [6].

Aneurysmal bone cyst $(\mathrm{ABC})$ is rare, benign vascular lesion, and considered secondary to certain pathological bone lesions [7]. ABC represents approximately $1.4 \%$ of all bone tumors, and only $3 \%$ among those are located in the cranium [8]. These lesions occur most commonly in patients under 20 years old of both genders [8]. Radiographs reveal an eccentric, lytic lesion typically with an expanded, remodeled "blown-out" or "ballooned" bony contour of the affected bone, with a delicate trabeculated

\footnotetext{
* Correspondence: abdullahast@hotmail.com

'Department of Otolaryngology - Head and Neck Surgery, King Fahad Medical City, Riyadh - Saudi Arabia

Full list of author information is available at the end of the article
}

appearance frequently. Fluid-filled spaces are common and may be seen on CT scans and MR images [7].

Concomitant FD and $\mathrm{ABC}$ are extremely rare with only 13 cases reported previously [9-12]. The clinical presentation of both FD and $\mathrm{ABC}$ depends on their location and the extent of involvement. The majority of reported cases are predominant in male children and young adults that are presented with symptomatic or asymptomatic mass. The development of $\mathrm{ABC}$ in $\mathrm{FB}$ may hastens the course of presentation [12]. In general, a complete excision of these lesions is recommended, and reports of aggressive behavior are occasionally found.

We report a rare example of concomitant FD and $\mathrm{ABC}$ of the skull base that presented with blindness and rapid local recurrence in a 7 year-old female patient. Also, we are presenting the multidisciplinary team approach of treating such cases.

\section{Case report}

A 7 year-old female, is presented at a local hospital with left eye blindness and discharge of one-month duration.

Physical examination showed a slightly proptotic left eye with no light perception, absence of direct pupil reflex and optic nerve atrophy in the left eye. In addition to, a slight hypertelorism. Otolaryngologic examination showed rhinorhea, bulging hard palate, and a left nasal mass (Figure 1).
C Biomed Central

(c) 2011 Terkawi et al; licensee BioMed Central Ltd. This is an Open Access article distributed under the terms of the Creative Commons Attribution License (http://creativecommons.org/licenses/by/2.0), which permits unrestricted use, distribution, and reproduction in any medium, provided the original work is properly cited. 


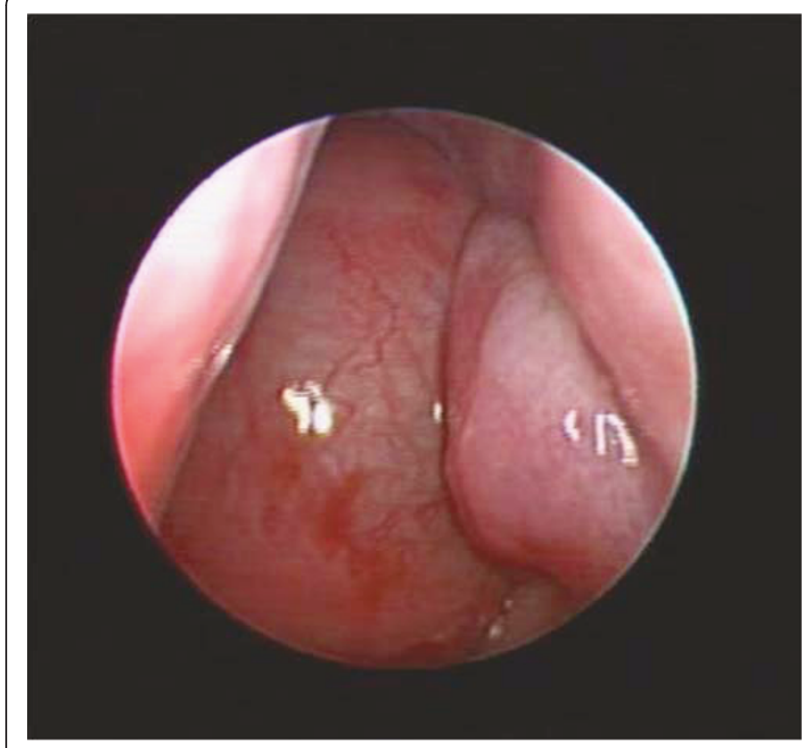

Figure 1 Endoscopic nasal view of left nostril, revealed huge nasal mass that occupied the whole cavity and reach to the level of inferior turbinate.

Preoperative CT findings (Figure 2, A) were consistent with fibrous dysplasia involving the sphenoid, ethmoidal sinuses, and posterior aspect of the nasal cavity as well as, the left maxillary sinus and the left optic foramen. Large expansible cystic spaces were also noticed in the lesion on preoperative MRI (Figure 3). Endoscopic biopsies revealed fibrous dysplasia with vascular component that were associated with significant and difficult to control bleeding.

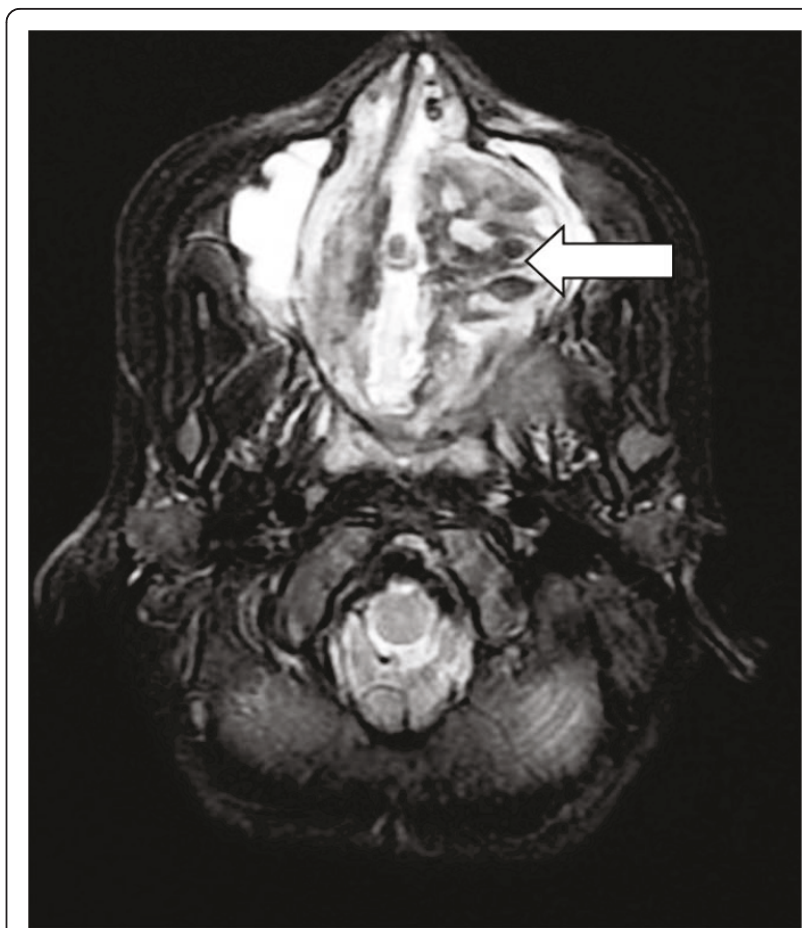

Figure 3 Preoperative Axial T2 of the skull base revealed multiple fluid-fluid levels with hemorrhagic areas (white arrow) are consistent with associated aneurysmal bone cyst.

\section{Surgical Excision}

A combined endonasal-cranial approach to resect this lesion that entailed an extradural bi-coronal craniotomy (pericranium saving technique for closure) and medial bilateral orbitotomy was performed (Figure 2, B). The preoperative assessment of the tumor (using the

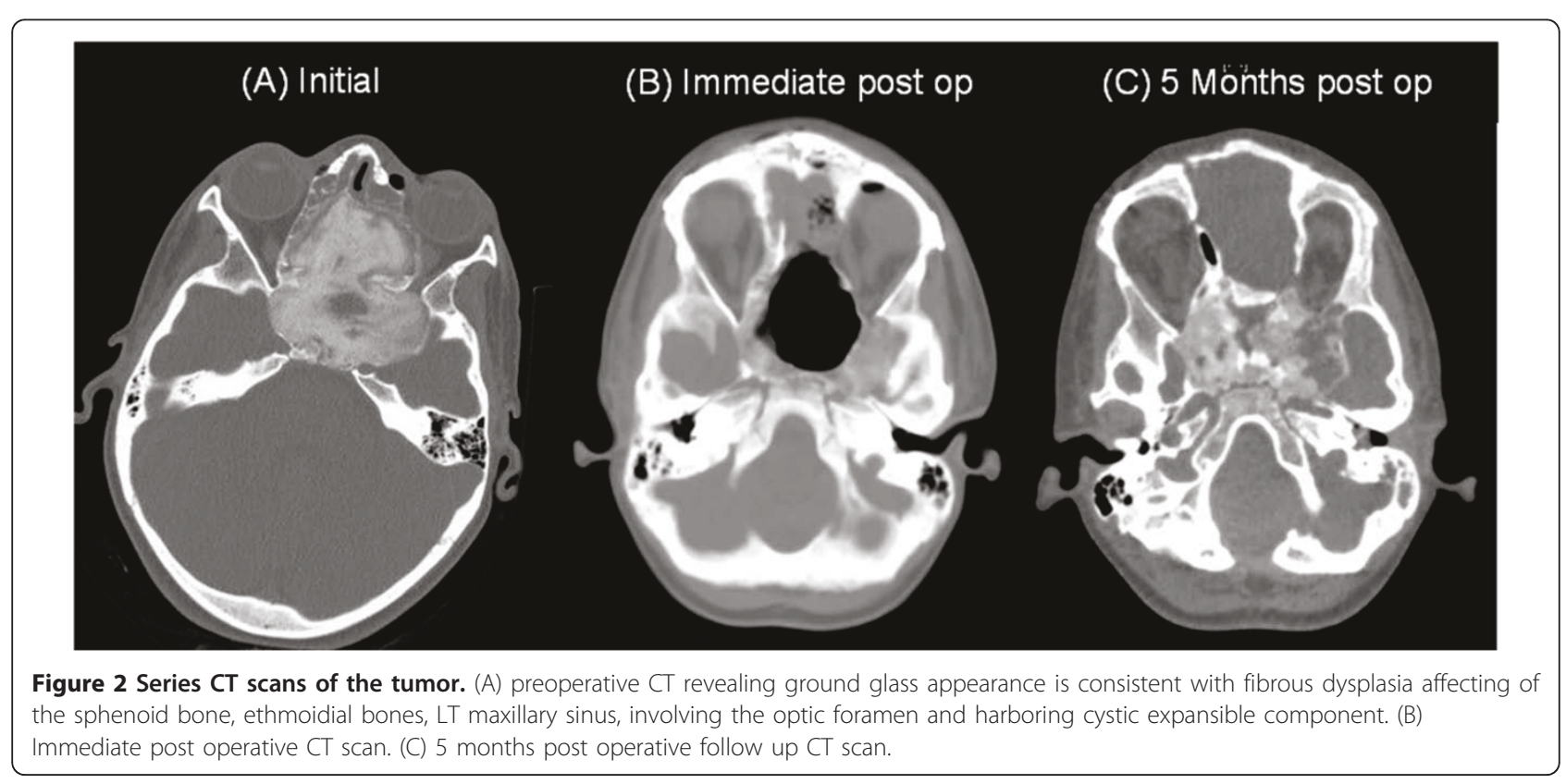


neuronavigation system) revealed a volume of $88.67 \mathrm{cc}$, approximately $95 \%$ ( $84.17 \mathrm{cc}$ ) of the tumor was removed. $4.5 \mathrm{cc}$ was left over the right optic nerve to preserve the vision on the unaffected eye. The intraoperative blood loss was estimated about $1700 \mathrm{cc}$. And the patient recovered without any appreciable complications, along with improvement of her proptosis. She was discharged with clinical and imaging follow up.

\section{Histopathology}

Histological evaluation revealed fibroblastic proliferation comprised of benign fibrous spindle areas with mature irregular bone formation (Figure 4). Cystic formation and hemorrhagic spaces lined by osteoclast-like multinucleated giant were also noted (Figure 5). The findings were consisted of fibrous dysplasia with aneurismal bone cyst-like features.

\section{Follow-up}

Five months after surgery, a recurrent large tumor was noticed, estimated to be $30.5 \mathrm{cc}$ (Figure 2, C). The patient's parents declined any further treatment, and the patient was lost to follow up.

\section{Discussion}

We present a rare case of FD with $\mathrm{ABC}$ in the skull base of a female child with sudden blindness. The radiological and pathological findings were consistent with the diagnosis in this case. In contrast to previous reports, however, the present case progressed rapidly and led to bone destruction and extension to adjacent vital structures. Saito et al [12] presented a similar case involving the nasal cavity and the sphenoid sinus with

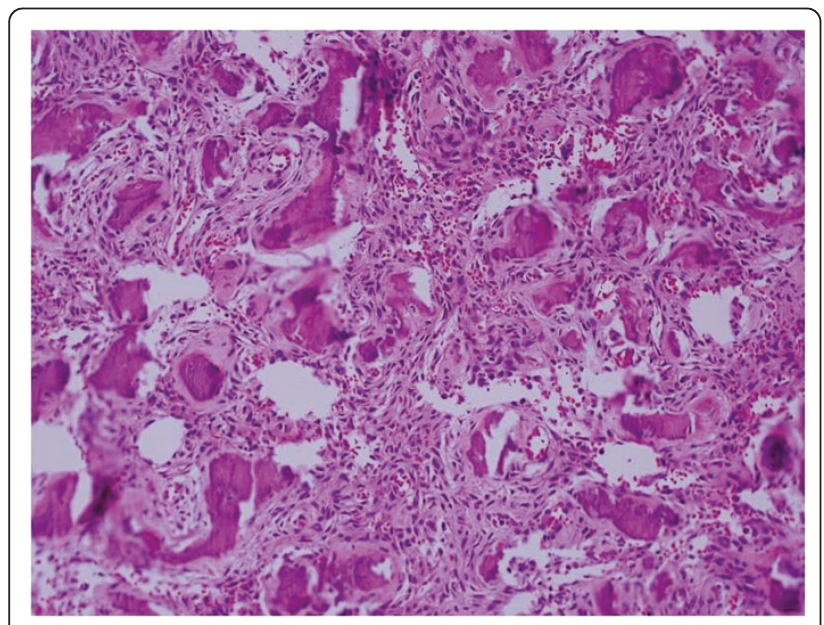

Figure 4 Fibrous dysplasia. Photomicrograph reveling spindle cells proliferation with islands of mature bone structure (with Chinese like characters). No mitosis or cellular features of malignancy are presented.

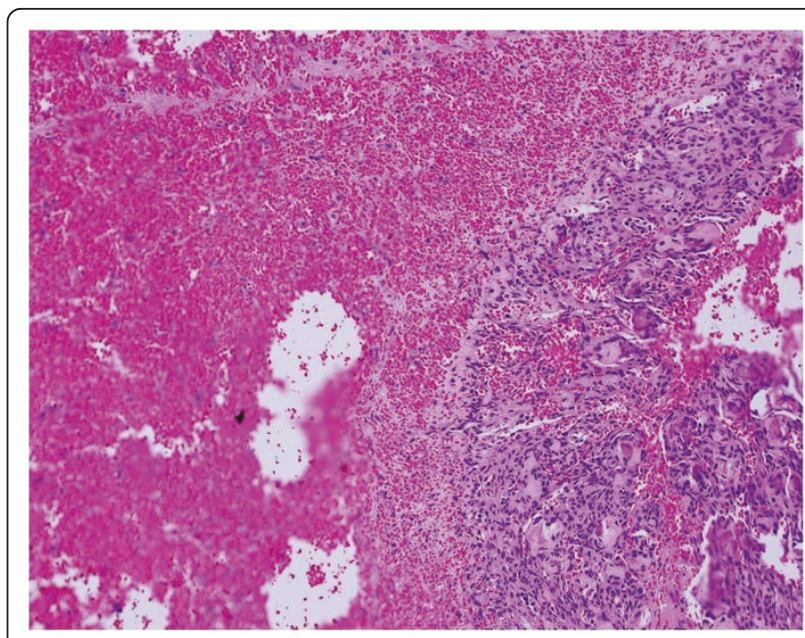

Figure 5 Aneurysmal bone cyst. Photomicrograph shows spindle cell proliferation with giant cell lining bloody cystic structure.

symptoms that preceded the diagnosis by one year. In their case, complete excision was achieved with no recurrence after 3.5 years of follow up. Of the [11] concomitant FD and ABC that have been reported (Table 1 [8-18]), $[9,13,14,16-18]$, three occurred in the sinonasal cavity $[8,12,13,15]$.

The presentation of these lesions, as in our case, depends on the location, rate of growth and site of involvement. Symptoms may include painless mass, pressure symptoms, nasal obstruction, headache and loss of vision. Acute hemorrhage into the cyst(s) may causes pain, rapid enlargement and/or rupture and subarachnoid hemorrhage [18]. All reported cases were treated surgically with generally good outcomes.

$\mathrm{ABC}$ in distal tibia has been treated by high-energy, lowdose radiation on one patient and was successful, with no recurrence during the five years follow up [19]. However, radiation for $\mathrm{ABC}$ of skull base or concomitant $\mathrm{ABC}$ with $\mathrm{FD}$ residual tumors has not been reported. The aggressive nature of the present case and others suggests that adjuvant therapy may be required in some cases.

\section{Conclusion}

Our case represents a rapid developing fibrous dysplasia with aneurismal bone cyst at the skull base leading to unilateral blindness. Awareness of such cases may lead to early detection and diagnosis for effective therapy.

A multidisciplinary team is needed for both diagnosis (clinical, radiological, and histopathological) and management (otolaryngology, neurosurgery, and neuronavigation) in this kind of diseases.

\section{Consent}

Written informed consent was obtained from the patient for publication of this case report and accompanying 
Table 1 Clinical, radiological findings, and treatment of reported combined fibrous dysplasia and aneurysmal bone cyst of the skull

\begin{tabular}{|c|c|c|c|c|c|c|}
\hline Reference & $\begin{array}{l}\text { Age } \\
\text { (years) } \\
\text { Gender }\end{array}$ & Site & Clinical presentation & Radiological findings & $\begin{array}{l}\text { Treatment/Surgical } \\
\text { approach }\end{array}$ & $\begin{array}{l}\text { Follow- } \\
\text { up }\end{array}$ \\
\hline $\begin{array}{l}\text { Składzień } \\
\text { et al., } 2008 \text { [8] }\end{array}$ & $16 / M$ & Rt Maxillary, orbital & $\begin{array}{l}\text { Epistaxis and chronic } \\
\text { rhinosinusitis }\end{array}$ & Large cystic lesion & En-bloc excision & $\begin{array}{l}9 \text { mo } \\
\text { disease } \\
\text { free }\end{array}$ \\
\hline $\begin{array}{l}\text { Rappaport, } \\
1989 \text { [9] }\end{array}$ & $25 / M$ & Lt occipital & Painful mass & $\begin{array}{l}\text { CT: pagetoid changes } \\
\text { and hypodense lesion }\end{array}$ & Surgical excision & No f/u \\
\hline $\begin{array}{l}\text { Wojno and } \\
\text { McCathy, } \\
1994[10]\end{array}$ & $14 / F$ & Rt temporal & Painless mass & $\begin{array}{l}\text { CT: nonhomogeneous } \\
\text { cystic lesion }\end{array}$ & Surgical excision & $\begin{array}{l}2 \mathrm{yr} \\
\text { disease } \\
\text { free }\end{array}$ \\
\hline $\begin{array}{l}\text { Wojno and } \\
\text { McCathy, } \\
1994[10]\end{array}$ & $40 / M$ & Lt frontal & $\begin{array}{l}\text { Expanding mass } \\
\text { Mass appear after head trauma }\end{array}$ & $\begin{array}{l}\text { CT: diffuse thickening of } \\
\text { the calvarium, Lt frontal } \\
\text { cyst }\end{array}$ & Surgical excision & No f/u \\
\hline $\begin{array}{l}\text { Haddad et al., } \\
1998[11]\end{array}$ & $6.5 / M$ & Rt temporal & Rt painless temporal mass & $\begin{array}{l}\mathrm{CT} \text { : nonhomogeneous } \\
\text { cystic mass. }\end{array}$ & Frontotemporal excision & $\begin{array}{l}4 \text { yr } \\
\text { disease } \\
\text { free }\end{array}$ \\
\hline $\begin{array}{l}\text { Saito et al. } \\
1998[12]\end{array}$ & $11 / \mathrm{M}$ & $\begin{array}{l}\text { nasal cavity, } \\
\text { sphenoid bone, and } \\
\text { skull base }\end{array}$ & $\begin{array}{l}\text { Nasal obstruction and headache } \\
\text { for } 1 \mathrm{yr}\end{array}$ & $\begin{array}{l}C T \text { and } M R I \text {, irregular } \\
\text { multilobulated tumor }\end{array}$ & Craniofacial excision & $\begin{array}{l}3.5 \mathrm{yr} \\
\text { disease } \\
\text { free }\end{array}$ \\
\hline $\begin{array}{l}\text { Branch et al., } \\
1986[13]\end{array}$ & $9 / F$ & $\begin{array}{l}\text { Lt parietal \& fronto- } \\
\text { temporal }\end{array}$ & $\begin{array}{l}\text { Painful Lt and frontal parietal } \\
\text { mass for } 1 \mathrm{mo}\end{array}$ & $\begin{array}{l}\mathrm{CT} \text { : large cystic bone } \\
\text { lesion in the parietal } \\
\text { area }\end{array}$ & Surgical excision & No f/u \\
\hline $\begin{array}{l}\text { Branch et al., } \\
1986[13]\end{array}$ & $19 / M$ & Rt parietal & $\begin{array}{l}\text { Painless mass } \\
\mathrm{k} / \mathrm{c} \text { of FD for } 15 \mathrm{yr}\end{array}$ & $\begin{array}{l}\text { CT: cystic expansion of } \\
\text { the skull }\end{array}$ & Surgical excision & No f/u \\
\hline $\begin{array}{l}\text { Itshayek et al., } \\
2002\end{array}$ & 19/M & $\begin{array}{l}\text { Lt occipital bone } \\
\text { and clivus }\end{array}$ & $\begin{array}{l}\text { Painless mass of the occipital } \\
\text { area }\end{array}$ & CT: occipital cyst lesion & $\begin{array}{l}\text { Selective embolization. } \\
\text { Followed by surgical } \\
\text { resection. }\end{array}$ & $\begin{array}{l}1 \mathrm{yr} \\
\text { disease } \\
\text { free }\end{array}$ \\
\hline $\begin{array}{l}\text { Pasquini } \\
\text { et al., } 2002 \\
{[15]}\end{array}$ & $5 / \mathrm{M}$ & Rt maxillary sinus & $\begin{array}{l}\text { Progressive and persistent Rt } \\
\text { side epiphora and rhinosinusitis } \\
\text { for } 2 \mathrm{yr} \text {. }\end{array}$ & CT: Cyst-like lesion. & $\begin{array}{l}\text { Transnasal endoscopic } \\
\text { surgery }\end{array}$ & No f/u \\
\hline $\begin{array}{l}\text { Lin et al., } \\
2004[16]\end{array}$ & $18 / \mathrm{M}$ & Lt frontal bone & $\begin{array}{l}\text { Progressive enlargement of the } \\
\text { mass with severe headache }\end{array}$ & $\begin{array}{l}\text { CT: several expansile } \\
\text { cystic spaces }\end{array}$ & Surgical resection & No f/u \\
\hline $\begin{array}{l}\text { Iseri et al., } \\
2005[17]\end{array}$ & $35 / F$ & Lt occipital bone & Progressive severe headache & $\begin{array}{l}\text { FD of clivus, temporal, } \\
\text { and occipital bones. }\end{array}$ & Unresectable & \\
\hline $\begin{array}{l}\text { Mattei et al., } \\
2005[18]\end{array}$ & 19/M & Occipital bone & $\begin{array}{l}\text { As } \mathrm{SAH} \text {; severe headache and } \\
\text { nuchal rigidity. }\end{array}$ & Hemmorage and cyst & Partial surgical resection & No f/u \\
\hline Our case & $7 / F$ & $\begin{array}{l}\text { Sphenoidal and } \\
\text { ethmoidal bones }\end{array}$ & $\begin{array}{l}\text { Lt eye loss of vision } \\
\text { Lt nasal obstruction }\end{array}$ & Cystic expansible lesion & $\begin{array}{l}\text { Endonasal - cranial } \\
\text { resection }\end{array}$ & $\begin{array}{l}\text { Recur } \\
\text { after } 5 \\
\text { mo }\end{array}$ \\
\hline
\end{tabular}

FD; fibrous dysplasia. AG; angiogram. LPMA; Lt posterior meningeal artery. SAH; subarachnoid hemorrhage. ABC; aneurysmal bone cyst. f/u; follow up. k/c; known case.

PNS; paranasal sinuses.

images. A copy of the written consent is available for review by the Editor-in-Chief of this journal.

\section{Acknowledgements \\ We are grateful to Dr. Adel El-Naggar for his great influence in reviewing this manuscript, Dr. Suhail Maqbool for his helpful guidance in writing the manuscript and patient management, and Dr. Mahmoud Al-Yamany for helping in innovating and performing the skull base approach.}

\section{Author details}

'Department of Otolaryngology - Head and Neck Surgery, King Fahad Medical City, Riyadh - Saudi Arabia. ${ }^{2}$ Department of Radiology, King Fahad Medical City, Riyadh - Saudi Arabia. ${ }^{3}$ Department of Neurosurgery, King Fahad Medical City, Riyadh - Saudi Arabia. ${ }^{4}$ Department of Pathology, King Fahad Medical City, Riyadh - Saudi Arabia.
Authors' contributions

AST: writer, alignment and drafted the manuscript. KHQ: surgen, writer. EB: radiological diagnosis, writer. LS: neuronavigation, writer. ABM: pathological diagnosis, writer. AJS: surgen, writer. All authors read and approved the final manuscript.

\section{Competing interests}

The authors declare that they have no competing interests.

Received: 10 January 2011 Accepted: 11 March 2011 Published: 11 March 2011

\section{References}

1. Edgerton MT, Persing JA, Jane JA: The surgical treatment of fibrous dysplasia with emphasis on recent contributions from cranio-maxillofacial surgery. Ann Surg 1985, 202:459-479. 
2. Feldman MD, Rao VM, Lowry LD, Kelly M: Fibrous dysplasia of the paranasal sinuses. Otolaryngol Head Neck Surg 1986, 95:222-225.

3. Harrison DFN: Unusual tumors. In Cancer of head and neck. Edited by: Suen JY, Myers EN. Churchill-Livingstone, New York; 1981:829-876.

4. Albright F, Butler AM, Hampton AO, Smith PH: Syndrome characterized by osteitis fibrosa disseminata, areas of pigmentation and endocrine dysfunction, with precocious puberty in females: report of five cases. $N$ Engl I Med 1937, 216:727-746.

5. Ham DW, Pitman KT, Lassen LF: Fibrous dysplasia of the clivus and sphenoid sinus. Military Med 1998, 163:186-189.

6. Bibby K, McFadzean R: Fibrous dysplasia of the orbit. Br J Ophthalmol 1994, 78:266-270.

7. Kransdorf MJ, Sweet DE: Aneurysmal bone cyst: concept, controversy, clinical presentation and imaging. AJR 1995, 164:573-580.

8. Składzień J, Oleś K, Zagólski O, Moskała M, Sztuka M, Strek P, Wierzchowski W, Tomik J: A giant cranial aneurysmal bone cyst associated with fibrous dysplasia. B-ENT 2008, 4:29-33.

9. Rappaport ZH: Aneurysmal bone cyst associated with fibrous dysplasia of the skull. Neurochirurgia 1989, 32:192-194.

10. Wojno KJ, McCarthy EF: Fibro-osseous lesions of the face and skull with aneurysmal bone cyst formation. Skeletal Radiol 1994, 23:15-18.

11. Georges F Haddad, Hambali Fadi, Mufarrij Amjad, Nassar Anis, Fuad S Haddad: Concomitant Fibrous Dysplasia and Aneurysmal Bone Cyst of the Skull Base. Pediatr Neurosurg 1998, 28:147-153.

12. Saito Kiyoshi, Fukuta Keizo, Takahashi Masakatsu, Yukio Seki, Youshida Jun: Benign fibroosseous lesions involving the skull base, paranasal sinuses, and nasal cavity. Report of two cases. J Neurosurg 1998, 88:1116-1119.

13. Branch CL, Challa VR, Kelly DL: Aneurysmal bone cyst with fibrous dysplasia of the parietal bone. Report of two cases. J Neurosurg 1986, 64:331-335.

14. Itshayek Eyal, Spector Sergey, Gomori Moshe, Ricardo Segal: Fibrous dysplasia in combination with aneurysmal bone cyst of the occipital bone and the clivus: case report and review of the literature. Neurosurgery 2002, 51:815-818.

15. Pasquini Ernesto, Compadretti Ceroni Giacomo, Sciarretta Vittorio, Ippolito Antonio: Transnasal endoscopic surgery for the treatment of fibrous dysplasia of maxillary sinus associated to aneurysmal bone cyst in a 5-year-old child. Int J Pediatr Otorhinolaryngol 2002, 62:59-62.

16. Wen-Chiung Lin, Wu Hondar Hung-Ta, Chao-Jung Wei, Chang Cheng-Yen: Aneurysmal bone cyst arising from fibrous dysplasia of the frontal bone (2004:2b). Eur Radiol 2004, 14:930-932.

17. Pervin K Iseri, Efendi Husnu, Demirci Ali, Komsuoglu Sezer: Fibrous Dysplasia of the Cranial Bones: A Case Report and Review of the Literature. Yale Journal of Biology and Medicine 2005, 78:139-143.

18. Mattei TA, Mattei JA, Ramina R, Aguiar PH: Fibrous dysplasia in combination with aneurysmal bone cyst presenting as a subarachnoid haemorrhage. Neurol Sci 2005, 26:178-181.

19. Kamikonya N, Hishikawa Y, Kurisu K, Taniguchi M, Miura T: Aneurysmal bone cyst treated by high-energy, low-dose radiation therapy: a case report. Radiat Med 1991, 9(2):54-6.

doi:10.1186/1758-3284-3-15

Cite this article as: Terkawi et al:: Fibrous dysplasia and aneurysmal bone cyst of the skull base presenting with blindness: a report of a rare locally aggressive example. Head \& Neck Oncology 2011 3:15.

\section{Submit your next manuscript to BioMed Central and take full advantage of:}

- Convenient online submission

- Thorough peer review

- No space constraints or color figure charges

- Immediate publication on acceptance

- Inclusion in PubMed, CAS, Scopus and Google Scholar

- Research which is freely available for redistribution

Submit your manuscript at www.biomedcentral.com/submit
Biomed Central 